\title{
Róża Różańska
}

JaGiELLONIAN UniVERSITY IN KRAKÓW

\section{Leone Leoni as a Forgotten Composer of the Early Baroque Era}

\section{Abstract}

The article is a pioneer attempt in Polish literature to develop a synthetic resume and the characteristics of the work of the Italian Baroque composer Leone Leoni. Leoni was highly valued in his time; also, he is said to be one of the creators of dramma per musica genre, and his religious compositions served as model examples of counterpoint for many centuries. The first part of the text presents the state of research concerning the life and work of the artist; then, the second part contains his biography. The last part discusses Leoni's works. Finally, the rank of his output is regarded.

\section{Keywords}

Leone Leoni, small-scale concerto, madrigal, early Baroque

The following article is a pioneer attempt in Polish literature to develop a synthetic resume of life and art of Leone Leoni (ca. 1560-1627), an Italian composer. Today forgotten, he was a highly valued artist in his epoch. He is regarded as one of the pioneers of dramma per musica and, 
through the centuries, his church music was used by music theorists as models of music rhetoric and concertato style in the compositions for small ensemble.

The paper has been planned as an introduction to the cycle of articles dedicated to Leone Leoni, and because of that it is general in the character. The first part presents the state of studies on life and art of this artist. The second part consists of Leoni's biography. The third part is dedicated to his compositional output, including periodisation of his compositions. The last part discusses the issue of reception and indicates the role of the composer, documented in analogies and theoretical works that mention his works. The author hopes that both this article and the planned cycle will provoke the interest in this artist and encourage to further studies.

\section{State of Research}

Leone Leoni is currently a half-forgotten persona. The name of this artist active in Vicenza does not appear in the general literature of history of music, ${ }^{1}$ we will not find him also in the most important syntheses concerning his epoch. ${ }^{2}$ The composer is mentioned only by two authors: Manfred Bukofzer, who finds him a follower of Andrea Gabrieli's style of suggestive expressiveness, ${ }^{3}$ and Julie Anne Sadie, who, when writing of him in the dictionary of Italian artists in the section Venice, makes us associate him with Venetian school. ${ }^{4}$ The composer was presented also in the most important English and German

Compare: e.g. R. Taruskin, The New Oxford History of Music, Oxford 2005.

2 Compare: A.W. Atlas, Renaissance Music. Music in Western Europe, 1400-1600, New York 1998; L.L. Perkins, Music in the Age of the Renaissance, New York 1999; G. Reese, Music in the Renaissance, New York 1954; The Cambridge History of SeventeenthCentury Music, ed. J. Butt, T. Carter, Cambridge 2005; J.W. Hill, Baroque Music. Music in Western Europe, 1580-1750, New York 2005.

3 M. Bukofzer, Muzyka w epoce baroku. Od Monteverdiego do Bacha, transl. into Polish by E. Dziębowska, Warszawa 1970, p. 44.

4 J.A. Sadie, Companion to Baroque Music, London 1990, p. 31. 
encyclopedias, ${ }^{5}$ and among Italian works, he is included in Dizionario Enciclopedico Universale della Musica e dei Musicisti ${ }^{6}$ and Dizionario Biografico degli Italiani. ${ }^{7}$ In Polish literature, we have a biography prepared by Magdalena Wiącek in Encyklopedia Muzyczna PWM. ${ }^{8}$ Still, there is lack of any monograph dedicated to this artist.

Also, the compositional output of Leoni is described rarely, although in the 2oth century, the single works were written about this topic, both in Europe and in the USA. Certain interest in the Italian artist was initiated by Giovanni Mantese in 1956, when he published a book describing history of music in Vicenza, although the publication only mentions Leoni. ${ }^{9}$ The first wider analysis was made ten years later, by the American Henry Wing, who in his dissertation examined the polychoral motets of this composer; ${ }^{10}$ however, it was the last paper that shows interest in Leoni out of his homeland. Four years later, Susan Suglich wrote a $\mathrm{PhD}$ dissertation about Leoni as a musician from region of Veneto at the University of Padua. ${ }^{11}$ The last signal of interest in this artist in the academic environment is a $\mathrm{PhD}$ dissertation written by Guido Simoni from the 1980s, which concerns the 5th Book of Madrigals of the member of Accademia Olimpica. ${ }^{12}$

The name of Leoni is also mentioned in the context of studies on the musical repertoire of the countries outside Italy, as-because of

5 S. dal Belin Peruffo, Leoni, Leone [Leo], [in:] The New Grove Dictionary of Music and Musicians, ed. S. Sadie, vol. 14, p. 564; R. Tibaldi, Leoni, Leone, [in:] Die Musik Geschichte und Gegenwart. Allgemeine Enzyklopädie der Musik, ed. L. Finscher, vol. 10, pp. 1612-1614.

6 S. Durante, Leoni, Leone, [in:] Dizionario enciclopedico universale della musica e dei musicisti, ed. A. Basso, vol. 4, Torino 1999, pp. 372-373.

7 W. Cupperi, Leoni, Leone, [in:] Dizionario biografico degli Italiani, vol. 64, ed. M. Carevale, Roma 2005. See also: [online] http://www.treccani.it/enciclopedia/leone-leoni_(DizionarioBiografico)/ [accessed: 27.03.2017].

8 M. Więcek, Leoni, Leone, [in:] Encyklopedia Muzyczna PWM. Część biograficzna, ed. E. Dziębowska, vol. 5 (KLE), Kraków 1997, p. 327.

9 G. Mantese, Storia musicale vicentina, Vicenza 1956.

$10 \mathrm{H}$. Wing, The Polychoral Motets of Ludovico Balbi and Leone Leoni, PhD dissertation, Boston University, Boston 1966.

11 S. Suglich, Leone Leoni musicista veneto, $\mathrm{PhD}$ dissertation, Universita degli Studi di Padova, Padova 1970.

12 G. Simioni, Il quinto libro dei madrigali di Leone Leoni, $\mathrm{PhD}$ dissertation, Universita degli Studi di Pavia, Pavia 1984-1985. 
many reprints of his works-his art is present also abroad. The topic of circulation of his music was, however, analyzed on the margin of several papers. It is worthy to pay attention to the book City Limits, edited by Glen Clark, Judith Owens and Greg T. Smith, where in the chapter written by Susan Lewis Hammond there is a notice of Danish king Christian IV, who reigned since $1588 .{ }^{13}$ In the more detailed way, the topic is discussed by the earlier text by Hammond: Italian Music and Christian IV's Urban Agenda for Copenhagen. ${ }^{14}$ The same author also indicates Leoni's works that were known in the area of Germany. ${ }^{15}$

Leone Leoni is sometimes mentioned also as a student of Giammateo Asola, the Kapellmeister of the Vicenza Cathedral. The name of the composer from Verona-as a successor of maestro di cappella and the creator of the valued collection Canti sacri from 1608-is mentioned by the author of introduction to the edition of the complete works edition by Asola. ${ }^{16}$

All mentioned texts only fragmentarily discussed the topic of the composer. Among musicologists, only Vittorio Bolcato in his papers widely described Leoni among his contemporary artists and in the musical environment of Vicenza at the turn of the 16th and the 17th

13 S.L. Hammond, Renaissance Venice as a Musical Model for Copenhagen, [in:] City Limits. Perspectives on the Historical European City, ed. G. Clark, J. Owens, G.T. Smith, Montreal-Ithaca 2010, pp. 88-106. Susan Hammond mentions many pieces by Leoni that are in inventory of the royal collection in Copenhagen. Among them, there are eight madrigals from prints of catalogue number: L1992, L1995 and L1996. The court composer Melchior Borchgrevinck probably valued Leoni, because In his two-volume anthology of madrigals Giardino novo he placed as many as eight of Leoni's compositions, among works of such composers as Claudio Monteverdi and Luca Marenzio. Hammond explains a huge number of Leoni's madrigals by the accessibility of Venetian prints with his compositions from years 1588-1602 in the time immediately before the publication of Giardino novo, i.e. before years 1605-1606.

14 S.L. Hammond, Italian Music and Christian IV's Urban Agenda for Copenhagen, "Scandinavian Studies" 2005, No. 3, pp. 365-382.

15 S.L. Hammond, Editing Italian Music for Lutherian Germany, [in:] Orthodoxies and Heterodoxies in Early Modern German Culture. Order and Creativity, 1500-1750, ed. R.C. Head, D. Christensen, Leiden-Boston 2007, pp. 117-139. The researcher mentions the topic of the content of anthology Il trionfo di Dori, she also cites texts of madrigals by Leoni translated into German.

16 D.M. Fouse, introduction to edition, [in:] G. Asola, Sixteen Liturgical Works, series «Recent Researches in the Music of the Renaissance», vol. 1, New Haven 1964. 
century. ${ }^{17}$ The most important achievement of the researcher in this field was to create the thematic catalogue of the works by the composer, ${ }^{18}$ what was preceded by the detailed research on church archives of Vicenza made by Albert Zanotti. ${ }^{19}$ Unfortunately, precious texts by Bolcato have not been translated into English, and because of that they remain unknown to the wider public.

Also the works by Leoni are still difficult to access, because there is lack of contemporary editions of them. The only exception is the collection published by the small American publisher Artemisia Editions, ${ }^{20}$ that contains six compositions by Leoni from the fourth book Sacri fiori. ${ }^{21}$ Because of that, Leone Leoni's compositions are so rarely performed.

\section{Life of Leoni ${ }^{22}$}

Leone Leoni, also known as Leo Leoni, was born ca. 1560 in Verona and died in Vicenza in 1627. There is lack of documents concerning his education, but we can assume that as a clergyman he was educated in Scuola degli Accoliti in Verona, ${ }^{23}$ and later he received

17 V. Bolcato, Un nuovo capitolo della storia musicale del Seicento a Vicenza la Capella dell'Incoronata nella cattedrale, [in:] Musica, scienza e idee nella Serenissima durante il Seicento, ed. F. Rossi, F. Passadore, Venezia 1993, pp. 43-51.

18 V. Bolcato, Leone Leoni e la musica a Vicenza nei secoli XVI-XVII. Catalogo tematico, Venezia 1995.

19 V. Bolcato, A. Zanotti, Il fondo musicale dell'Archivio Capitolare del Duomo di Vizenza, Torino 1986.

20 Four Mottets for 1-3 Voices by Alba Tressina and Six Mottets for 2-4 Voices (with Violins) by Leone Leoni from Sacri Fiori, Libro quarto (Venice 1622), series "Complete Collections by Nun Composers», cat. No. CC 05a. The transcription was made based on the old print kept in the Jagiellonian Library. The publishing catalogue with the further information about pieces: [online] http://cappellaartemisia.com/artemisia-editions-catalogue/ [accessed: 28.03.2017].

21 They are following compositions: Haec est, Congregate sunt, O quam tu pulcher, Iste Sanctus, Sumite citharas and Laudate Dominum.

22 Life and output of Leoni were described based on: S. dal Belin Peruffo, op. cit.; W. Cupperi, op. cit.

23 The conclusions are made by V. Bolcato in the introduction to his thematic catalogue. See: V. Bolcato, Leone Leoni e la musica..., op. cit., p. LVII. 
Lower Orders. The composer himself claimed that he was a student of Sebastiano Torsi, ${ }^{24}$ an artist who was highly valued in Verona; these words were confirmed by another musician from the environment of Count Bevilacqua.

The musical activity of Leoni can be reconstructed only based on faint clues. The first of them is preserved libretto from the tragedy Tamar $^{25}$ based on the biblical motifs, with choral parts composed by the creator of Sacri fiori. It was published in Vicenza in 1586 and is the evidence for the presence of the composer in this city; unfortunately, music for this work is lost. The base for the conclusions about the following stages in the composer's life are evidences of his colaboration with significant artistic institutions. It is highly probable that Leoni's patron when he visited Verona was Marco Bevilacqua, and in Vicenza the composer conjoined the Accademia Olimpica ${ }^{26}$ (Leoni names himself a member of this institution in the introduction to Bella Clori from 1591). ${ }^{27}$ In 1585, Oedipus Rex by Sophocles was performed in Vicenza in the translation of Orsalto Giustiniani, ${ }^{28}$ with choruses of Andrea Gabrieli; the piece was probably enriched by music of Leoni. ${ }^{29}$ On the 3 rd of March 1585 this composition opened the activity of the Accademia Olimpica. According to Angelo Ingegneri, ${ }^{30}$ who participated in the performance of Oedipus, the chorus consisted of fifteen

24 Ibid, p. LXVI: "D. Sebastian de Torsi diecti Pigna profesoris de Musica", after the document Antifico uff. Del Registro, kept in Archivio di Stato di Verona (cat. No. $212 \mathrm{nn} .60 / 61$ ). Mentioned Sebastiano Pigna was an addressee of a dedication of the first book of Sacri Fiori from 1606. Tamar. Attione tragica di Gio. Battista di Velo rappresentata nella citta di Vicenza dalla Compagnia nova l'anno MDLXXXVI, Vicenza 1586.

${ }^{26}$ Compare: W. Cupperi, op. cit.; V. Bolcato, Leone Leoni e la musica..., op. cit., pp. LXVI-LXVIII. Bolcato pays attention to dedication of the introduction of I Book of Madrigals and Motets written by Leoni from 1588, that was written to Bevilacqua. D. Arnold, Vicenza, [in:] The New Grove Dictionary of Music and Musicians, ed. S. Sadie, vol. 26, London-New York 2001, pp. 528-530.

30 Angelo Ingegneri (1550, Venice-1613, Venice) - an Italian poet writing in the Venetian dialect, a friend of Torquato Tasso, he influenced the final shape of the title of epic poem Jerusalem Delivered. See: A. Siekiera, Ingegneri Angelo, [in:] Dizionario Biografico degli Italiani, vol. 62, ed. M. Carevale, Roma 2004. See also: [online] http://www.treccani.it/ enciclopedia/angelo-ingegneri_(Dizionario-Biografico)/ [accessed: 28.03.2017]. 
elder and august members, and according to Antonio Riccoboni, the witness who described this event in the letter to a friend, the chorus consisted of cherubs and young women [sic!] ${ }^{31}$ Oedipus was a successful masterpiece of the young composer-the example of a modern piece, broadening the genre of motet and madrigal, close stylistically to dramma per musica.

The next stages of the career of the composer are also documented in the preserved sources. On the 3oth of April 1588, Leoni asked a bishop for the possibility to receive investiture from the parish at Saint Stridonio's church, where on the 26th of June 1588 he became a lector and exorcist, and on the 29th of June he was ordained an acolyte. ${ }^{32}$ In order to complete lower orders, Leoni received a document with annotation "dimissorie", prepared on the 24th of April 1587 by the vicar of Verona Pietro Stridonio. ${ }^{33}$ Because of it, the holy order of Leoni should have taken place in 1588 in his family city. However, it is not confirmed in sources. Documentation until 1604 was destroyed during the flood in 1882. What is more interesting, in Collazioni ss. Ordini (1578-1592) of parish of Vicenza, ${ }^{34}$ extremely important sources for the subject, his holy orders were not noted; Leoni is not even mentioned among deacons and subdeacons, although this register contains all paid pensions and benefits, which for the Diocese of Vicenza were fixed for 40 ducats. Leoni, like all subdeacons, would have to be written in a register to

31 Compare: W. Cupperi, op. cit.

32 V. Bolcato, Leone Leoni e la musica..., op. cit., p. LVIII.

33 "Die Dominico 26. mensis Junij 1588. Supradictus Illustrissimus et Reverendissimus Dominus Episcopus in Sacello Sancti Nicolai palatij sui episcopalis presentibus, et asistentibus RR.DD. Thadeo Zilineto, et Francisco Moyse promouit, et ordinauit ad ordinem Lectoratus, et exor istatus. Dominum Leonem de Leonibus Clericum Veronensem cum litteris dimissorialibus Ad R. D. Petri Stridonij Vicarij episcopatus Veronae diei 24 aprilis. 1587. manu sua, ac sigillo munitis, et per Dominum Franciscum a lege cancellarium subscriptis Die Veneris 29 dicti in qua die celebratur Festum Sancti Petri. Praedictus Illustrissimus et Reverendissimus Dominus Episcopus in Sacello ac praesentubus et asistentibus suprascriptis promouit, et ordinauit ad Accolytatus suprascriptum Dominum Leonem de Leonibus Clericum Veronensem cum litteris dimmissoralibus ut supra Boscarinus de Boscarinis episcopatus Vicentini Cancellarius scripsit". Collazioni SS. Ordini 1/o787 Registro (1578-1592), Citation from: V. Bolcato, Leone Leoni e la musica..., op. cit., p. LVIII.

34 Compare: V. Bolcato, Leone Leoni e la musica..., op. cit., p. LIX. 
receive cash benefits. It is difficult to explain the cause of this situation without detailed research in the diocesan archives.

The choice of Leoni as maestro di cappella of the Santa Maria Annunciata Cathedral of Vicenza took place on the 29th of June 1588, on the day when he was ordained an acolyte, together with paying him a salary-4 ducats. ${ }^{35}$ Leoni remained on this position until his death, despite the attempts to find a different job. Despite his duties of Kapellmeister, Leoni was very active in Accademia Olimpica. He belonged to other institutions as well: in 1593, he became a member of Confraternità del Divino Amore, set up by Gaetano Thiene, ${ }^{36}$ and in 1610 he was chosen as maestro della musica of the new Pia Opera dell'Incoronata. ${ }^{37}$

During his long ministry and work for the Cathedral Chapel in Vicenza, Leoni suffered numerous disappointments and also fell into conflict with the church authorities. In 1606, the composer was excommunicated for failing to recognize Paul V's interjection to Serenissima, as he traveled to Venice like many other priests from Vicenza Cathedral to celebrate mass. ${ }^{38}$ As a result, there were no ceremonies in Venice at that time, and even papal diplomacy left the city. ${ }^{39}$ On the 28 th of April 1593 he went to Venice to get acquittal. Then, on the 6th of July 1593, he sent a petition to the canonry of Vicenza Cathedral, wanting a higher salary, and he expressed his frustriation after dismissal in dedication of the compositions, even mentioning the plan to leave the city. ${ }^{40}$ The

35 "1588. die martis. 4 octobris in loco capitulari [...] R.di: d.d. Portus de Portis Archid: Scipionus Trissinus Archipresbiter Nicolaus de S.o. Severino Io:bapta de Gualdo, Ambrosius saracenus, Gellinus de gellino, Ipolitus cauacionus ac Paulus de Gualdo. omnes canonici vocemque in capitulo habentes Quoniam alias fuit ellectus pro magistro capellae R.dus Presbiterus Leonus de Leonus loco presbiteri d. Joannis macradij substituti et usque ad huc ipsi non fuerit assignatum sallarium idem R.dus Archid.s proposuit patrem quod assignetur ipse junii prixima preteriti qua pars guit ballotata per dictos d.d. Canonicos cum bussolis et ballotis occultae redditis de omnis suis fragijs obtinuit”. Collazioni SS. Ordini 1/o787 Registro (1578-1592), a citation from: V. Bolcato, Leone Leoni e la musica..., op. cit., p. LIX. Ibid., p. LXI.

$37 \quad$ Ibid.

38 Ibid., p. LXII. G. Mantese also cites about it, paying special attention to the dedication of the collection Sacri Fiori, published in Venice in 1606. See: idem, op. cit., p. 56.

39 J. Garbacik, Polska wobec konfliktu Wenecji z papieżem Pawłem V, "Collectanea Theologica" 1938, 19/2, pp. 145-176.

40 V. Bolcato, Leone Leoni e la musica..., op. cit., pp. LXII-LXIII. 
next financial problems took place in 1604, when Church did not receive financial benefits from the resources of musical chapel S. Pietro. ${ }^{41}$ Because of mentioned reasons, Leoni tried to improve his material status-he stopped dedicating his publications to the clergymen of Vicenza and started dedicating them to secular and significant authorities such as prince-bishop of Salzburg, Wolf Dietrich von Raitenau, cardinal of Trident, Carlo Gaudenzio Madruzzo, bishop of Verona. ${ }^{42}$

In spite of numerous sad events, the composer had also financial successes. In 1610, thanks to generous donations of the faithful gathered in Lent, a new institution was funded-the already mentioned Pia Opera dell'Incoronata, created for performing music during prayers of Litany to Mother of God, recited on all Saturdays of the year, and devotions to her. ${ }^{43}$ The amount of these funds also allowed for the creation of an ensemble under guidance of Leoni. Thanks to the Pia Opera, new music appeared in the cathedral, for solo voices, choir, string instruments, winds and organ, performed by maestro della musica and other musicians active in the city. ${ }^{44}$

The composer died on the 24th of June 1627 in Vicenza and was buried, in accordance with his will, in the cathedral near the matroneum. In his will, he mentioned as heirs his successors in the position of clergyman of the Cathedral and other people related to his place of employment. ${ }^{45}$

41 W. Cuperri, op. cit.

${ }^{42}$ V. Bolcato, Leone Leoni e la musica..., op. cit., pp. LXIII-LXIV.

${ }^{43}$ Ibid., p. LXV.

44 W. Cupperi, op. cit.

45 "In Christi nomine amen, anno ad ipsius nativitate millesimo sexcentesimo vigesimo septimo, inditione X, die martis 22 iunii Vicentiae domi perillustris et admodum rev. di d. tastatoris posita in contracta ut dicitur dietro le mura del Palamaio pubblicato die 24 iunii 1627 per me notarium infrascriptum ut aparet in libro decretorum d. Julii carcani notarii ad officium Sigilii reperitur hoc legatum, videlicet. Heredi universali di tutti li miei beni mobili e stabili, presenti e future di ogni sorte voglio che siano et instituisco li $[\ldots]$ molto rev.di Canonici et molto rev.di Mansionari, unitamente, del Domo, con obligo d'eseguir quanto ordino di sopra alli miei comissari et anco che siano venduti tutti li miei beni et che del pro di quelli, pagato che sara tutti li interessi st chi havera d'havere, sii fatto un salario per dir tante Messe alla settimana quante potera et impotera la mia faculta per l'anima mia et pe altri secondo la mia intentione. Eccettuato pero ducati 50 quali voglio che siano dati alli rev.di mansionari et cio per sodisfazione della mia concienza, et il resto dalli miei comissari sii dato in salario di dir le sudette Messe. Et ego Lucas filius q. Peregrini de Dominicis publicus auctoritate notarius his omnibus singulisque interfui atque scripsi et in formam redegi". Citation from: V. Bolcato, Leone Leoni e la musica..., op. cit., p. LXVI. 
What influenced Leone Leoni's art was his contact both with representatives of the Palestrina's tradition, and followers of the Florentine Camerata. After graduating from the acolites' school, Leoni started his professional life by contacting the environment of humanists of view close to Florentine Camerata's concepts-because of that, the majority of the repertoire from the first stage of his activity was secular music. Later years of his artistic activity, the proportion of repertoire changed. Gaining the position of Kapellmeister of Vicenza Cathedral, Leoni devoted himself to church music. Despite this, the marks of experience gained during his work for Accademia Filarmonica are visible in his church compositions. ${ }^{46}$

Preserved sources show the variable output of Leoni in terms of genres. As it was mentioned before, the art of this composer can be divided into two individual stages connected with different inclinations in preferred genres: a) secular, in years 1586-1602 (the artist composed 218 madrigals and 4 songs that time) and b) sacred-from 1606 to 1622 (142 motets as well as psalms and masses were created that time). ${ }^{47}$ We do not know if the artist stopped composing in last years of his life or the works created at that time have not been preserved until today.

The art of Leoni was published in following prints and anthologies: ${ }^{48}$

- Collections of madrigals:

1. Il primo libro de madrigali a 5 voci (1588).

2. Bella Clori. Secondo libro de madrigali a 5 voci (1591).

3. Il terzo libro de madrigali a 5 voci (1595).

4. Penitenza. Primo libro de madrigali spirituali a 5 voci (1596).

5. Il quarto libro de madrigali a 5 voci (1598).

6. Bellalba. Quinto libro de madrigali a 5 voci (1602).

46 W. Cupperi, op. cit.

47 Periodisation and typology from W. Cupperi, op. cit.

48 Titles of collections and information about place of publishing after: W. Cupperi, op. cit. If it is not marked differently, the place of publishing is Venice. 
- Madrigals in anthologies:

7. Di pastorali accenti, madrigale a 6 voci, [in:] Il trionfo di Dori (1592).

8. D'un lauro all'ombra, madrigale a 6 voci, [in:] Madrigali pastorali. Il bon bacio (1600).

9. Io per la via del sangu'e della morte, madrigale a 5 voci, [in:] Parte delli pietosi affetti di Angelo Grillo (1598).

- Canzonettes:

10. 2 canzonette, [in:] Il primo libro delle canzonette a 3 voci, ed. C. Baselli (160o).

11. 2 canzonette, [in:] Il secondo libro delle canzonette a 3 voci, ed. C. Baselli (1600).

- Prints of non-liturgical sacred music:

12. Sacri fiori. Mottetti a 2, 3 e 4 voci per cantar nel organo, libro primo (1606).

13. Sacrarum cantionum liber primus cum duplici partitura organi (1608).

14. Sacri fiori. Secondo libro de motetti a 1,2 e 3 voci per cantar nel organo con una messa a 4 voci (1612).

15. Omnium solemnitatum psalmodia a 8 voci (1613).

16. Prima parte dellaurea corona ingemmata d'armonici concerti a 10 con 4 voci e 6 strumenti in lode della Santissima Incoronata di Vicenza (1615).

17. Sacri fiori. Quarto libro de motetti a 1, 2, 3 e 4 voci, con il basso per sonar nell'organo (1622).

- Non-liturgical sacred music published in anthologies:

18. In convertendo, salmo a 5 voci, [in:] Sacra omnium solemnitatum psalmodia vespertina (1592).

19. Dum canerent arguto, mottetto a 6 voci, [in:] Hortus musicalis, liber tertius (München 1609). 
- Mass settings:

20. Agnus Dei, per 2 cori e 4 voci, [in:] Responsoria hebdomadae sanctae (1612).

21. Aperi mihi mea sponsa, mottetto a 2 voci, [in:] Il primo libro de motetti a 1, 2, 3, e 4 voci, raccolti da don Stefano Corradini (1624).

22. Messa a 12 voci (3 cori) super Ab Austro veniet. ${ }^{49}$

- Lost collections:

23. Sacri Fiori, terzo libro de motetti.

24. The collection of sacred music, almost for sure anthems, published in 1602, belonging to Archive of the Chapter of Vicenza Cathedral.

In order to know better the character of analyzed repertoire, we will examine the main factors that influenced the composer in both periods of his artistic activity. The beginning of the Leone Leoni's activity is associated with his home city, Verona. The composer remained there under protection of Count Mario Bevilacqua (1536-1593), ${ }^{50}$ a patron of art, who since 1568 was a member of Accademia Filarmonica of Verona. Comprehensively educated aristocrat graduated from law in Bologna, but he always focused on the tasks connected with culture. In his Palazzo Bevilacqua, built by Michele Sanmicheli circa 1535, he created a museum of Greek and Roman antique monuments, a gallery and library. At this place there were also meetings of his popular ensemble, called ridotto. Among professional musicians of ridotto were: Sebastiano Pigna, Paolo Masnelli, Ercole Pasquini and Domenico Lauro. Also Stefano Bernardi was probably a choir singer there as a boy. Pietro Pontio dedicated to this ensemble his work Ragionamento di musica written in 1588. What the author indicated, "it is a place in which almost every day many high born develop their skills of

49 Kept in Vienna, Österreichische Nationalbibliothek, Musiksammlung, 16707b. The date of publication is unknown.

50 The description of the Count presented on the basis of: E. Paganuzzi, Bevilacqua, Mario, [in:] The New Grove Dictionary of Music and Musicians, ed. S. Sadie, vol. 3, London 1995, p. 497. 
playing, singing and discussion about many similar subjects". Bevilacqua was a prominent patron, what is mirrored by works dedicated to him, composed by such artists as: Orlando di Lasso, Luca Marenzio, Orazio Vecchi, Claudio Merulo, Philippe de Monte, Girolamo della Casa, Tiburtio Massaino, Gabriele Martinengo, Filippo Nicoletti and Maddalena Casulana. Leoni, collaborating with the circle of musicians of Count, had also a possibility to develop his compositional talent, he as well had access to numerous instruments.

As all researches underline, the characteristic feature of Leoni's works is their new style. However, despite that the composer felt the innovative atmosphere of Venice, the first stage of his compositional activity is characterized rather as an attempt to sustain the Palestrinian style. In madrigals, predominating during this stage, Leoni referred to the experience of his masters, especially in terms of relations between text and music. At the same time, we can distinguish several madrigals in which the artist searched for new means of expression. ${ }^{51}$ The example of that would be the composition Vorei, vorei scoprire from the fourth book of madrigals, ${ }^{52}$ in which the major part of the piece consists of the soprano voice consistently repeating the last stanza, "ma non lo posso dire", in a comic dialogue with the rest of the voices, and at the same time changing the character of a whole piece. Generally, in compositions from the whole fourth book, we can look for the general tendency to repeat phrases (called ostinata traccia by Bolcato), e.g. in Fugge quest'empia fiera. Two madrigals have virtuoso onomatopoeic ornaments written in two upper voices-in Dimmi Clori gentil perché non armi, from the fifth book, they appear together with the words "Usignolo alla lontana" ("nightingale in a distance") and "Risposta in ecco all'usignolo nascosto di lontano" ("responds the nightingale hidden in a distance"). We can describe these solutions as anticipation of the techniques characteristic for the madrigal rappresentativo. On the other hand, in nine-voice Il ciel vi faccia lieti almi pastori, for the first time in Leoni's composition the polychoral technique is used, that was frequently used in sacred music

51 Compare: V. Bolcato, Leoni Leone e la musica..., op. cit., and W. Cupperi, op. cit.

52 L. Leoni, Il quarto libro de madrigali a 5 voci, Venezia 1598. 
at that time, and here it was written in the two-part form of madrigal with contrasted parts. ${ }^{53}$

The second stage of Leoni's activity, in which the composer devoted himself to sacred music, is characterized by the stylistic change towards the achievements of the most representative artists of the new music, e.g. Claudio Monteverdi, Carlo Gesualdo da Venosa or Lodovico da Viadana. ${ }^{54}$ Thanks to that, Leoni, interested in church music for small ensemble, is mentioned together with them by Adrian Banchieri in Cartella musicale (1613) as an example of the author "esempi moderni applicati a parole volgari, et latine". ${ }^{55}$

Church music is the most significant part of the Leoni's work. His motets from the collection Corona Aurea ${ }^{56}$ (written "for the pride of the Most Holy Mother of God of Vicenza") are-because of the novelty of solutions-the culmination of the composer's achievements. They use the concerto style, in which two instrumental parts are individual voices, not doubling the vocal lines. These pieces are characterized by the dialogue between solo and tutti, usually virtuoso beginning episodes and short imitations divided by homorhythm in further fragments. ${ }^{57}$ The anthology is very interesting also because of diversity of sounds and used instruments. Also, stylistic techniques typical for new music for small ensemble can be found there, which are known from his two first books of motets and from madrigals. What appears is the tone painting that is present in madrigals, ${ }^{58}$ as well as specific use of stile rappresentativo, present, for example, in polychoral motet Beata es Virgo from the collection Corona Aurea, in which choir with the accompaniment of chitarrone or organ repeats the second chorus of alto voice twice, to express words "da lontano" ("from far"). ${ }^{59}$

53 L. Leoni, Bell'alba. Quinto libro de madrigali a 5 voci, Venezia 1602. The description of the works from: V. Bolcato, Leoni Leone e la musica..., op. cit. and W. Cupperi, op. cit.

54 V. Bolcato, Leone Leoni e la musica..., op. cit., p. LXVII.

55 A. Banchieri, Cartella musicale [...], Venezia 1613, pp. 208-210.

56 Aurea corona ingemmata diarmonici, concerti a 10 voci, Venezia 1615 . The compositions consist of 25 motets for 4 vocal parts and 6 instrumental. It preserved in a manuscript copy.

57 V. Bolcato, Leone Leoni e la musica..., op. cit., p. LXV.

58 S. dal Belin Peruffo, op. cit.

59 This is an interpretation of the fragment presented by V. Bolcato. Compare: idem, Leone Leoni e la musica..., op. cit., p. LXIV. 
As we remember, the earlier musical experience of Leoni associated him strongly with Palestrinian generations of artists, shaping his later compositional technique. Leoni received the thorough musical education in area of counterpoint even in his hometown under guidance of Giammateo Asola ${ }^{60}$ his predecessor on the position of Kapellmeister of the Vicenza Cathedral. Born in Verona in 1532, died in Venice in 1609, Asola probably studied with Vincenzo Ruffo in his hometown. He was closely connected with Church environment. ${ }^{61}$ In 1577 , he was appointed maestro di cappella in the Cathedral of Treviso, but after a year he accepted a better offer at the cathedral in Vicenza. Most probably in $\mathbf{1 5 8 2}$ he went to Venice, where he remained until his death. ${ }^{62}$ Leoni is one of the most important students of this composer.

So far, research for the poetic sources of madrigals and motets has allowed to claim that Leoni used the art of local poets. For example, in the composition Di pastorali accenti from the anthology Il trionfo di Dori he uses text by Maddalena Campiglia, associated with the court of Gongaza in Mantua. ${ }^{63}$ The composer also set to music poems by Pomponio Montenaro from Verona and Valerio Bella from Vicenza and other writers, whose poems were published in Venice, Padua and Ferrara-cities being in close relations to Vicenza. However, the majority of texts from the composer's pieces remains unidentified. ${ }^{64}$

Ecclesiastical concerts appear in the composer's output only in the second period of his creative activity, i.e. after 1606. Leoni published four collections of works in this genre, all of which have a common

${ }^{60}$ The biography and art of Asola described on the basis of: D. Fouse, Asola Giammateo, [in:] The New Grove Dictionary of Music and Musicians, ed. S. Sadie, vol. 2, London 1995, pp. 114-115.

61 On the 7th of May 1546, Asola joined the congregation of secular canons at Santo Giorgio in Alga. From 1566 to his death, he received the benefits from Santo Stefano in Verona. After 1569, he decided not to make religious vows, he left the congregation, remained a secular priest, and from 1571 began work at the parish of Santa Maria in Organo in Verona. Compare: ref. 62.

62 In 1588, Asola became one of the four priests of Santo Severo, a church under jurisdiction of monks of Santo Lorenzo. In years 1590-91, his arrival to Verona was noted, but until his death he worked in Santo Severo.

${ }^{63}$ Compare: V. Bolcato, Leone Leoni e la musica..., op. cit., p. LXIV.

64 W. Cupperi, op. cit. 
title Sacri fiori, with following numbers. The first book of Sacri fiori the composer published in 1606, dedicating it to Sebastian Pigna in the preface. The collection contains 21 concerts, including 8 concerts for two voices, 7 for three voices and 6 for four voices. These works are characterized by the presence of elements of both prima pratica and seconda pratica. ${ }^{65}$ The second book of Sacri fiori, dedicated to Cardinal Gaudenzi Madruzzo of Trento, consists of compositions for two choirs. The third book of Sacri fiori is now considered lost. The last, fourth, consists of concerts from one to four voice. The collections of Sacri fiori in Leoni's work were often attributed to a negligible role, as their compositions were judged as essentially irreversible from the compositional technique of contemporary artists. ${ }^{66}$

\section{Reception of Leone Leoni's Output}

Leone Leoni was a quite popular composer in his lifetime. ${ }^{67}$ The reception of his music is visible thanks to reprints of his compositions, both secular and sacral. The popularity of his motets can be measured by the number and frequency of publishing in Italy and abroad. For example, in every of his three parts of a famous anthology of Abraham Schadaeus, Promptuarii musici (published in 1611, $1612,1613),{ }^{68}$ there are 16 motets by Leoni, whereas in the series of anthologies Promptuarii musici concentus ecclesiasticos published

65 V. Bolcato, Leone Leoni e la musica..., op. cit., pp. LXXIX-LXXX.

66 Ibid., passim.

67 It is indicated particularly by V. Bolcato, compare: ibid., Leone Leoni e la musica..., op. cit. See also: W. Cupperi, op. cit.

68 Promptuarii musici sacras harmonias sive motetas [...] pars prima, quae concentus selectissimos, qui tempore hyemali SS ecclesiae usui esse possunt, comprehendit, 5-8vv, bc (org), 1611; Promptuarii musici [...] pars altera quae aestivi temporis festivitatibus dominicisque diebus selectiores concentus SS ecclesiae usui inservientes continet, 5-8vv, bc (org), 1612; Promptuarii musici [...] pars tertia quae exhibet concentus varios selectioresque, qui solennioribus sc. SS Trinitatis, S Joh. Baptistae, B. Virginis Mariae, SS Apostolorum [...] per totius anni curriculum inserviunt, 5-8vv, bc (org), 1613. 
by Johann Donfrid (in 1622, 1623, 1627) ${ }^{69}$ ten compositions by this composer were added. ${ }^{70}$

The presence of Leoni's works in those esteemed anthologies at that time proves his perception of being a good composer by his contemporaries. Let us recall that Schadaeus, who lived in the years 1566-1626 in Silesia, was the most famous German publisher of this period. His three-volume anthology of motets arranged according to the order of the liturgical year is one of the most important collections of this type in Protestant editions. ${ }^{71}$ The first part of the collection contains works by 43 composers, of which 33 come from Italy; in the second, there are 45 Italian examples from all 51 compositions, the last counts 52 Italian works among published 61. Among the authors included in the anthology by Schadaeus the one that appears the most frequently is Leoni. Francesco Biancardi is equally popular, there are also many motets by Agostino Agazzari, Giovanni Gabrieli, Luca Marenzio, Tiburtio Massaino and Benedetto Pallavicino. ${ }^{72}$ On the other hand, the collection of Donfrid (1585-1654), also arranged according to the liturgical order, was dedicated to the Catholic addressee. Among names of composers, there are composers of polyphony, such as Tomás Luis de Victoria, Luca Marenzio or Hans Leo Hassler, but also representatives of new styles-beside Leoni, there are: Lodovico Grossi da Viadana (a quite big amount of compositions from Cento concerti), composers from the Northern Italy, Giacomo Finetti and Serafino Patta, and those associated with Rome: Antonio Cifra, Agostino Agazzari and Antonio Catalani. ${ }^{73}$

${ }^{69}$ Promptuarii musici, concentus ecclesiasticos, 2-4vv, bc (org), e diversis iisque illustrissimis et musica laude praestantissimis huius aetatis authoribus, collectos exhibentis. Pars prima; Strasbourg 1622; Promptuarii musici, concentus ecclesiasticos ducentos et eo amplius, 2-4vv, bc (org) [...] Pars altera, Strasbourg 1623; Promptuarii musici, concentus ecclesiasticos 286 selectissimos, 2-4 vv, bc (org), e diversis et praestantissimis Germaniae, Italiae et aliis aliarum terrarum musicis [...] Pars tertia, Strasbourg 1627.

70 S. dal Belin Peruffo, op. cit.

71 J. Roche, Anthologies and the Dissemination of Early Baroque Italian Sacred Music, "Soundings" 1974, No. 4, pp. 6-12.

72 The whole list, see: O. Reimer, Schadaeus, Abraham, [in:] The New Grove Dictionary of Music and Musicians, ed. S. Sadie, vol. 22, London-New York 2001, pp. 425-426.

73 Compare: J. Roche, Donfrid [Donfried], Johann [Johannes], [in:] The New Grove Dictionary of Music and Musicians, ed. S. Sadie, vol. 7, London-New York 2001, pp. 466-467. 
What is more, the presence of polychoral motets by Leoni is visible also in the collections published in years 1605-1643 in Copenhagen, Strasbourg, Nuremberg, Munich, Leipzig, Ingolstadt, Trier and Dresden. ${ }^{74}$ Anthologies were created mainly in order to use them during school education, partly also for church use. In this way, the Leoni's output was widespread with equal success in the fighting environments of Catholics and Protestants. ${ }^{75}$

Works by Leoni as an exemplification of a good style were used also by music theorists. Athanasius Kircher in the VIII book of his famous Musurgia Universalis from $165 \mathrm{O}^{76}$ illustrates figure Antitheton, sive Contrapositum by a citation from Leoni's motet Ego dormio, et cor meum vigilat. Almost one hundred years after the composer's death, Giuseppe Ottavio Pitoni in the coursebook Guida armonica ${ }^{77}$ provided a citation from his eight-voice motet Vide Domino as an example of stile secondo. It is the last proof of the knowledge of Leoni's output before contemporary texts.

\section{Bibliography}

Arnold D., Vicenza, [in:] The New Grove Dictionary of Music and Musicians, ed. S. Sadie, vol. 26, London-New York 2001, pp. 528-530.

Atlas A.W., Renaissance Music. Music in Western Europe, 1400-160o, New York 1998.

Belin Peruffo S. dal, Leoni, Leone [Leo], [in:] The New Grove Dictionary of Music and Musicians, ed. S. Sadie, vol. 14, p. 564.

Bolcato V., Leone Leoni e la musica a Vicenza nei secoli XVI-XVII. Catalogo tematico, Venezia 1995.

\footnotetext{
74 V. Bolcato, Leone Leoni e la musica..., op. cit., p. LXV.

75 However, in the register of output and in catalogue of Vittorio Bolcato, there is lack of information about reception of concerts for small ensemble from Sacri fiori.

76 A. Kircher, Musurgia Universalis, Roma 1650, book VIII, p. 145.

77 G.O. Pitoni, Guida armonica, Roma 169o, book I, p. 72.
} 
Bolcato V., Un nuovo capitolo della storia musicale del Seicento a Vicenza la Capella dell'Incoronata nella cattedrale, [in:] Musica, scienza e idee nella Serenissima durante il Seicento, ed. F. Rossi, F. Passadore, Venezia 1993.

Bolcato V., Zanotti A., Il fondo musicale dell'Archivio Capitolare del Duomo di Vicenza, Torino 1986.

Bukofzer M., Muzyka w epoce baroku. Od Monteverdiego do Bacha, transl. into Polish by E. Dziębowska, Warszawa 1970.

The Cambridge History of Seventeenth Music, ed. T. Carter, J. Butt, Cambridge 2005.

City Limits. Perspectives on the Historical European City, rd. G. Clark, J. Owens, G.T. Smith, Montreal-Ithaca 2010.

Cupperi W., Leoni, Leone, [in:] Dizionario biografico degli Italiani, vol. 64, ed. M. Carevale, Roma 2005; see also: [online] http://www. treccani.it/enciclopedia/leone-leoni_(Dizionario-Biografico)/ [accessed: 27.03 .2017 ].

Fouse D., Asola Giammateo, [in:] The New Grove Dictionary of Music and Musicians, ed. S. Sadie, vol. 2, London 1995.

Garbacik J., Polska wobec konfliktu Wenecji z papieżem Pawłem V "Collectanea Theologica" 1938, No. 2, pp. 145-176.

Hammond S.L., Editing Italian Music for Lutherian Germany, [in:] Orthodoxies and Heterodoxies in Early Modern German Culture. Order and Creativity, 150o-1750, ed. R.C. Head, D. Christensen, Leiden-Boston 2007.

Harman R.A., Milner A., Late Renaissance and Baroque Music (c. 1525-c. 1750), series "Man and His Music. The Story of Musical Experience in the West», vol. 2, London 1959.

Hill J.W., Baroque Music. Music in Western Europe, 1580-1750, New York 2005.

Mantese D., Storia musicale vicentina, Vicenza 1956.

Paganuzzi E., Bevilacqua, Mario, [in:] The New Grove Dictionary of Music and Musicians, ed. S. Sadie, vol. 3, London 1995.

Patalas A., Katalog starodruków muzycznych ze zbiorów byłej Pruskiej Biblioteki Państwowej w Berlinie, przechowywanych w Bibliotece Jagiellońskiej w Krakowie, Kraków 1999. 
Perkins L.L., Music in the Age of the Renaissance, New York 1999.

Reese G., Music in the Renaissance, New York 1954.

Reimer O., Schadaeus, Abraham, [in:] The New Grove Dictionary of Music and Musicians, ed. S. Sadie, vol. 22, London-New York 2001. Roche J., Anthologies and the Dissemination of Early Baroque Italian Sacred Music, "Soundings" 1974, No. 4, pp. 6-12.

Sadie J.A., Companion to Baroque Music, London 1990.

Taruskin R., The New Oxford History of Music, vol. 1, Oxford 2005.

Więcek M., Leoni, Leone, [in:] Encyklopedia Muzyczna PWM. Część biograficzna, ed. E. Dziębowska, vol. 5 (KLE), Kraków 1997.

Wing H., The Polychoral Motets of Ludovico Balbi and Leone Leoni, $\mathrm{PhD}$ dissertation, Boston University, Boston 1966. 